\title{
An Empirical Analysis of the CNY Internationalization and Its Influencing Factors
}

\author{
Hongliang Chen \\ School of Economic, Jinan University, Guangzhou, China \\ Email: andy_jnu@126.com
}

How to cite this paper: Chen, H.L. (2019) An Empirical Analysis of the CNY Internationalization and Its Influencing Factors. Open Journal of Business and Management, 7, 194-208.

https://doi.org/10.4236/ojbm.2019.71014

Received: December 20, 2018

Accepted: January 8, 2019

Published: January 11, 2019

Copyright $\odot 2019$ by author(s) and Scientific Research Publishing Inc. This work is licensed under the Creative Commons Attribution International License (CC BY 4.0).

http://creativecommons.org/licenses/by/4.0/

\section{(c) () Open Access}

\begin{abstract}
Influenced by the development of international monetary system and the financial crisis, the promotion of $\mathrm{CNY}$ internationalization has gradually evolved into the dual needs of both domestic and overseas. According to the money demand function proposed by Friedman and selecting the semi-annual data from 1990 to 1998, this paper establishes the domestic monetary demand model of CNY and estimates the offshore stock of CNY from 1999 to 2015 by indirect measurement method. And we take this as a measure of CNY internationalization standards. On this basis, this paper establishes a semi-logarithmic model and makes an empirical study on the influencing factors of CNY internationalization by cointegration analysis. The empirical result shows that the expansion of China's economic scale and the current account surplus are conducive to promoting the process of CNY internationalization, but the impact of capital and financial account on the process of CNY internationalization is not significant.
\end{abstract}

\section{Keywords}

CNY Internationalization, CNY Offshore Stock, Indirect Calculation Method, Cointegration Analysis

\section{Introduction}

With the rapid development of China's comprehensive national strength and the continuous improvement of the level of opening to the outside world, CNY has been widely used in neighboring countries and regions. During the Asian financial crisis in 1997, our government promised not to devalue the CNY, which further enhanced the international reputation of CNY. In recent years, the Chinese government has made great efforts to promote the Silk Road Economic Belt and the maritime Silk Road in the 21st century, the implementation of the "Belt and 
Road" strategy, and the regional economic integration of China is gradually influencing the global scope. In this process, China's foreign trade scale and foreign investment and financing needs are increasing. With the CNY becoming a member of SDR and the deepening of Belt and Road's strategy, the scale of CNY circulation abroad will be further expanded, and the internationalization process of $\mathrm{CNY}$ will be paid more attention by all walks of life. Therefore, it is of great theoretical and practical significance to study the current process of CNY internationalization and analyze the specific influencing factors of $\mathrm{CNY}$ internationalization.

On the meaning of currency internationalization, Chinn and Frankel (2005) think, for both residents and non-residents all over the world, currencies with transaction, bookkeeping and storage functions are called internationalized currencies [1]. This can be used as the theoretical basis for analyzing the meaning of CNY internationalization. Li Daokui and Liu Linlin (2008) pointed out that CNY internationalization is mainly reflected in three aspects: first, a certain degree of circulation abroad; Secondly, the scale and market scale of financial products priced in CNY have been expanded, and gradually developed into the investment carrier of international financial institutions; Third, transactions settled in $\mathrm{CNY}$ are increasing and account for a certain proportion in international trade [2].

In the study of measuring the degree of currency internationalization, scholars at home and abroad have put forward many theories and methods to measure currency internationalization. Jiang Boke and Zhang Qinglong (2005) take the currency composition of debt as the starting point, take the developing countries as the carrier, and take the dollar, the yen and the euro as the object, to define their internationalization degree [3]. Zhang Guangping (2014) holds that the application of currency internationalization is mainly reflected in the foreign exchange trading volume of the currency, so trading volume can be used to measure the degree of currency internationalization in the international foreign exchange market [4]. Zhang Yingmei (2013) used the Matlab principal component analysis method to select 19 economic indicators related to currency to measure of the CNY internationalization [5]. Eichengreen (2011) measured and predicted the process of internationalization of US dollar and euro through historical data, concluding that the euro will surpass the US dollar and become the new currency with the highest degree of internationalization in the future. But he also points out that this is a slow process [6]. Wei Hao, Dai Jinping and Jin Xiaoting (2010) established five indicators: 1) the proportion of money in the reserves of central banks, 2) the proportion of currency in foreign exchange market, 3) the proportion of international trade settlement currency, 4) the share of special drawing rights, and 5) the proportion of international bond issuing currency, and then construct a comprehensive index to compare the degree of internationalization of different currencies, and draw the conclusion that the current international monetary pattern is gradually developing to the bipolar pattern [7].

In addition, about the influential factor on the degree of currency internationalization, Kannan (2009) investigates the decisive factors in the composition of 
foreign exchange reserves held by the central banks in countries through the econometric analysis of the collected data. Therefore, the decisive factors influencing the internationalization of different currencies are obtained indirectly [8]. Liu Yanjing (2012) concludes that the basic factor of currency internationalization is that a country occupies a large share in global output, trade and finance through the econometric analysis of dynamic panel. And the stability of domestic prices and the potential of currency appreciation will also help to increase the share of currencies in the international reserves of other central banks, but the conclusion that per capita output has little impact on the internationalization of currencies [9].

This paper takes the stock of CNY offshore as a measure of the degree of CNY internationalization, referring to Yu Daoxian and Wang Yun (2015) in [10], using four economic variables: China's real GDP, one-year time deposit interest rate, the rate of return of Shanghai Stock Exchange Index (SSE) and the interest rate of current deposit, to establish the model of monetary demand function in China, and the degree of internationalization of $\mathrm{CNY}$ is measured by indirect measurement method. Based on the results of indirect measurement, this paper uses cointegration analysis to test the influence of GDP development level and balance of payments structure on the internationalization of CNY.

The main contributions of this paper are as follows: on the one hand, considering that few scholars measure the degree of currency internationalization by establishing a model of monetary demand function, this paper starts from this point of view, applies the equilibrium of money market that the money supply is equal to the demand for money to estimate the stock of CNY offshore. On the other hand, considering that with the enhancement of China's comprehensive national strength, the expansion of foreign trade scale and the gradual opening of capital account, the impact of the balance of payments structure on the internationalization of CNY will be significantly enhanced. Thinking the economic output of a country and the influence of the balance of payments on the internationalization of $\mathrm{CNY}$, this is a supplement to the research content in this field.

\section{The Measurement of the Internationalization Degree of CNY}

In this paper, the offshore stock of CNY from 1999 to 2015 is taken as the measure of CNY internationalization, and the indirect measurement method is used to estimate the offshore stock of CNY. The offshore stock of CNY refers to the scale of CNY circulating outside mainland China. The reason why the indirect measurement method is used in this paper rather than the direct measurement method is that the direct calculation method is based on the CNY flow caused by people's cross-border economic activities. However, this will ignore the CNY flow caused by other ways, and the direct measurement method is more subjective, and the estimated value may have a large error. On the contrary, indirect measurement means that when the money market is in equilibrium, the money 
supply is equal to the money demand, then there are the CNY total supply and the domestic CNY money supply in corresponding period, and the difference between the two is the estimated value of the CNY offshore stock.

\subsection{The Theoretical Model of Indirect Measurement Method}

The key of indirect measurement is how to set the demand function of CNY in China. Therefore, this paper selects some economic variables based on Friedman (1956) monetary demand function in [11], and constructs the domestic monetary demand function model in China. In this paper, China's real GDP $\frac{\text { GDP }_{t}}{P_{t}}$ is used to measure the wealth factor. Thinking about the interest rate in China is still not completely market-oriented, the rate of return of fixed income securities $R_{b t}$ is chosen as the one-year time deposit interest rate. The return rate of Shanghai Stock Exchange $R_{e t}$ is chosen as the rate of return of risk securities and the interest rate of current deposit is chosen as the rate of return of holding currency $R_{m t}$. Then, this paper selects $R_{b t}-R_{m t}$ and $R_{e t}-R_{m t}$ as a measure of the opportunity cost of holding money. Assuming $r_{b t}=R_{b t}-R_{m t}$ and $r_{e t}=R_{e t}-R_{m t}$, the calculation model of domestic money demand function is as follows:

$$
\frac{M_{0 t}}{P_{t}}=\left(\frac{\mathrm{GDP}_{t}}{P_{t}}\right)^{\alpha_{1}} \cdot e^{\left(\alpha_{0}+\alpha_{2} \cdot r_{t}+\alpha_{3} \cdot r_{e t}+\varepsilon_{t}\right)}
$$

The Equation (2) obtained by logarithmic processing of the Equation (1) is as follows:

$$
\ln \left(\frac{M_{0 t}}{P_{t}}\right)=\alpha_{0}+\alpha_{1} \cdot \ln \frac{\mathrm{GDP}_{t}}{P_{t}}+\alpha_{2} \cdot r_{b t}+\alpha_{3} \cdot r_{e t}+\varepsilon_{t}
$$

The time series of the money demand function model established in this paper is biannual period. The variables are set up and the data sources are as follows: $M_{0 t}$ is the cash balance in circulation in China, and $P_{t}$ is the price level, measured by CPI index of the base period, $\mathrm{GDP}_{t}$ is the gross domestic product in China, $R_{b t}$ is the time deposit interest rate at the end of each issue, $R_{e t}$ is the rate of return of the Shanghai Stock Exchange Index of China, and $R_{m t}$ is the interest rate on current deposits in China. The data source is the CSMAR database and the sample data range of this section is from 1990 to 2015.

\subsection{The Estimation Process of Indirect Measurement Method}

There are three steps in the calculation of the offshore stock of CNY. The first step is to divide the sample data into two periods. This paper assumes that CNY can only circulate in China in the first period and CNY can circulate in and out of China in the second period. Considering that the Asian financial crisis in 1997 has greatly devalued the currencies of China's neighboring countries and regions, while the CNY has shown a trend of steady and moderate rise; In addition, under the influence of the Chinese government's commitment not to de- 
value the CNY in March 1998, there was a large-scale cross-border movement of the CNY in the surrounding countries and regions around 1998. Based on this, this paper regards 1999 as the dividing point of the sample range of this paper, that is to say, from 1990 to 1998 , CNY will only circulate in China, and from 1999 to 2015, CNY will begin to circulate at home and abroad.

The second step is to use the relevant data from 1990 to 1998 to estimate the parameters of the established CNY domestic monetary demand model and obtain the domestic money demand function in this period. In order to avoid the pseudo-regression problem caused by non-stationary time series data, the unit root test of each variable in the model is carried out to judge its stationarity, and the results are shown in Table 1.

Table 1 shows that both $\ln \frac{\mathrm{GDP}}{P}$ and $r_{b}$ are non-stationary time series. After the first order difference adjustment, the variables of the domestic demand function are all stationary series, that is, the first order single integration process, so the cointegration analysis can be carried out. Since the variables of the model are all first-order single-integration processes, referring to the practice of Hawkins (1997) in [12], this paper uses the E-G cointegration test method to determine whether there is a cointegration relationship between dependent variables and independent variables in the model. First of all, the ordinary least square regression of the above model is carried out by using the relevant data from 1990 to 1998 in China. The result of regression is shown in Table 2.

As can be seen from Table 2, on the one hand, the determination coefficient $R^{2}$ of the regression model is 0.9803 , which shows that the explanatory variables explain the variables well, and the fitting effect of the equation is better. On the other hand, all variables can pass the coefficient non-zero test at the significant level of $5 \%$, except that the difference between the return rate of

Table 1. ADF test for each variable of domestic money demand function.

\begin{tabular}{cccc}
\hline Variables & Method $(\mathrm{C}, \mathrm{T}, \mathrm{n})$ & ADF-Value & $P$-Value \\
\hline $\ln \left(\frac{M_{0}}{P}\right)$ & $(\mathrm{C}, \mathrm{T}, 0)$ & -4.605 & 0.003 \\
$\ln \frac{\mathrm{GDP}}{P}$ & $(\mathrm{C}, 0,0)$ & 0.252 \\
$r_{b}$ & $(0,0,0)$ & -2.083 & 0.163 \\
$r_{e}$ & -1.346 & 0.000 \\
$D\left(\ln \left(\frac{M_{0}}{P}\right)\right)$ & $(0,0,0)$ & -5.842 & 0.011 \\
$D\left(\ln \frac{\mathrm{GDP}}{P}\right)$ & $(\mathrm{C}, \mathrm{T}, 1)$ & -4.136 & 0.039 \\
$D\left(r_{b}\right)$ & $(\mathrm{C}, 0,1)$ & -3.038 & 0.000 \\
$D\left(r_{e}\right)$ & $(0,0,1)$ & -3.696 & 0.000 \\
\hline
\end{tabular}

Note: $D$ is the difference operator, $\mathrm{C}$ represents the test equation with intercept term, $\mathrm{T}$ represents the test equation with time trend term, and $\mathrm{n}$ represents the delay order of the variable. The data comes from CSMAR database. 
Table 2. The estimated results of domestic money demand function.

\begin{tabular}{cccccc}
\hline Variable & Intercept & $\ln \frac{\mathrm{GDP}}{P}$ & $r_{b}$ & $r_{e}$ & $R^{2}$ \\
\hline Coef. & -0.504 & 0.875 & -2.455 & -0.035 & \\
Std.err & 0.304 & 0.046 & 1.054 & 0.031 & 0.9803 \\
$P$-value & 0.110 & 0.000 & 0.028 & 0.272 & \\
\hline
\end{tabular}

Note: The data comes from CSMAR database.

Shanghai stock index and the interest rate of current deposit does not pass the significance non-zero test of $5 \%$.

About the reason that $r_{e}$ is not significant, this paper thinks that it is related to the investment tendency of Chinese residents. Figure 1 shows a time series diagram of stock turnover and volume in China stock market. It can be seen that before 1999, the trading scale of China stock market was relatively small. There were not many people investing in the stock market in China, and most of the residents preferred savings deposits. Therefore, the fluctuation of stock market yield has little effect on the demand of residents to hold currency, that is, the response of Chinese residents to stock market returns is not sensitive. Although the $r_{e}$ is not significant, considering the rapid increase of the trading scale of the A share market after 1999, this paper still includes the $r_{e}$ in the domestic demand function of CNY. Next, we carries on the unit root test to the residual error series $e_{1}$ corresponding to the above regression result, the test result is shown in Table 3.

The unit root test in Table 3 shows that there is no unit root at the level of 1\% significance, that is, the residual series is stable, so there is a long-term cointegration relationship between the explained variables and the explanatory variables in the above regression model. The domestic demand function of CNY estimated in this paper is stable, which can be used to calculate the offshore CNY stock indirectly in the next step.

The third step, we estimate the domestic currency demand of CNY from 1999 to 2015 through the domestic money demand model above. Then, we get the difference between the calculated value obtained from the model above and the real value of the cash in circulation in the corresponding period, that is the estimated value of offshore stock of CNY, which is recorded as $\mathrm{m}$ in this paper. The estimation results are shown in Table 4. And the estimated scale of CNY offshore stock from 1999 to 2015 and its proportion to M0 are shown in Figure 2.

\subsection{Analysis of the Results of Indirect Measurement}

According to the results of Table 4 and Figure 2, it can be seen that the trend of the scale of offshore stock of CNY goes through six periods. From 1999 to 2005, the offshore stock of CNY in China generally maintained an upward trend. But the rising speed is slow. During 2005-2008, China began to implement the reform of CNY exchange rate formation mechanism since July 2005, that is, the floating exchange rate system based on the management of a basket of currencies, 


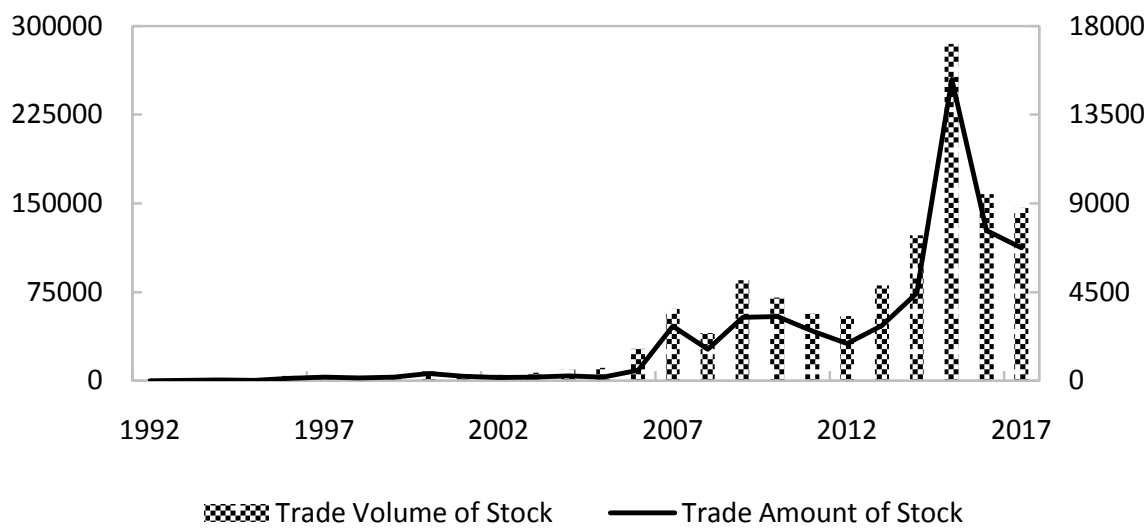

Figure 1. China stock market turnover in $1992-2017^{1}$.

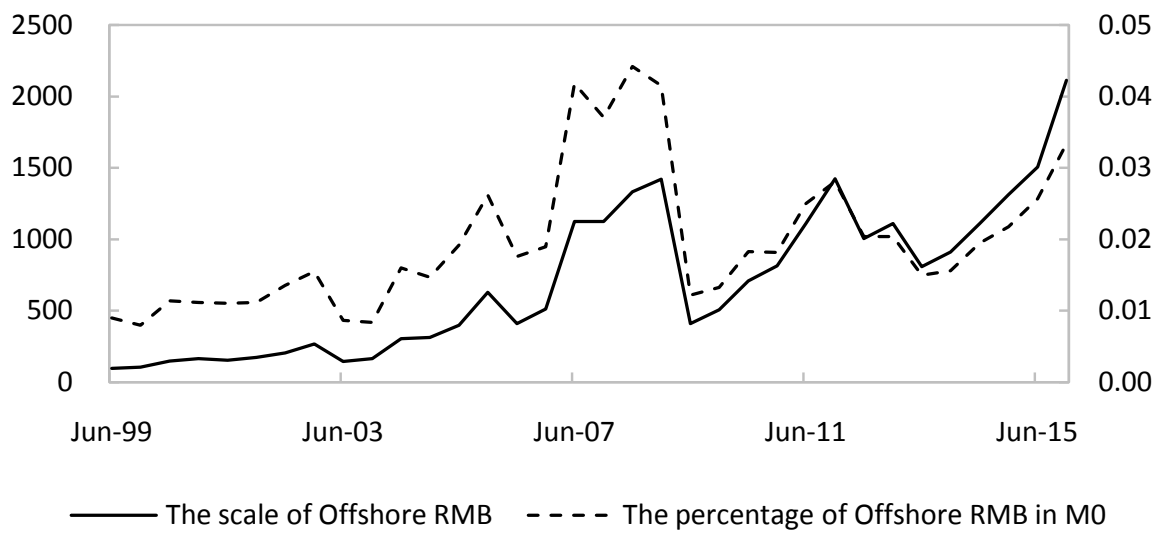

Figure 2. The scale of CNY offshore stock in 1999-2015².

Table 3. The unit root test of residual error $e_{1}$.

\begin{tabular}{cccc}
\hline Variables & Method $(\mathrm{C}, \mathrm{T}, \mathrm{n})$ & ADF-Value & $P$-Value \\
\hline$e_{1}$ & $(0,0,0)$ & -3.513 & 0.001 \\
\hline
\end{tabular}

Note: $\mathrm{C}$ represents the test equation with intercept term, $\mathrm{T}$ represents the test equation with time trend term, and $\mathrm{n}$ represents the delay order of the variable.

which is based on market supply and demand, has improved the floating nature of the CNY exchange rate. The gradual appreciation of CNY caused a relatively large increase in the offshore stock of CNY in this period. The outbreak of the global financial crisis in 2008 affected the development of China's economy and foreign trade. The Chinese government temporarily withdrew from the managed floating exchange rate system for the CNY. At the same time, with the deterioration of the global financial environment, a large number of renminbi returned to China. The stock of CNY abroad has declined sharply. Until June 2010, because the Chinese government expanded the pilot scope of CNY cross-border trade settlement and the CNY returned to the managed floating exchange rate system, ${ }^{1}$ The data of trade amount and volume includes Shanghai and Shenzhen stock exchange, which comes from CSMAR database.

${ }^{2}$ The scale of CNY offshore stock is estimated through the indirect measurement method, which shows in the Table 4. The data source is CSMAR database. 
Table 4. The estimation of offshore stock scale of CNY in 1999-2015.

\begin{tabular}{|c|c|c|c|c|}
\hline Year & $\begin{array}{l}\text { Real value of } \\
\qquad \ln \left(\frac{M_{0}}{P}\right)\end{array}$ & $\begin{array}{l}\text { Predicted value of } \\
\qquad \ln \left(\frac{M_{0}}{P}\right)\end{array}$ & $\begin{array}{c}\text { The share of } \\
\text { offshore CNY } \\
\text { stock in } M_{0}(\%)\end{array}$ & $\begin{array}{l}\text { Scale of offshore } \\
\text { CNY stock (100 } \\
\text { million yuan) }\end{array}$ \\
\hline $1999-6$ & 4.724 & 4.713 & 0.90 & 97.701 \\
\hline 1999-12 & 4.887 & 4.830 & 0.80 & 107.442 \\
\hline $2000-6$ & 4.891 & 4.793 & 1.14 & 147.807 \\
\hline 2000-12 & 4.962 & 4.941 & 1.12 & 164.756 \\
\hline $2001-6$ & 4.949 & 4.893 & 1.11 & 154.558 \\
\hline 2001-12 & 5.049 & 5.007 & 1.12 & 174.985 \\
\hline $2002-6$ & 5.031 & 4.971 & 1.36 & 204.682 \\
\hline $2002-12$ & 5.142 & 5.079 & 1.55 & 267.576 \\
\hline $2003-6$ & 5.140 & 5.065 & 0.87 & 147.084 \\
\hline 2003-12 & 5.247 & 5.236 & 0.84 & 165.096 \\
\hline 2004-6 & 5.239 & 5.198 & 1.60 & 305.107 \\
\hline 2004-12 & 5.355 & 5.228 & 1.47 & 315.176 \\
\hline $2005-6$ & 5.338 & 5.333 & 1.92 & 400.684 \\
\hline 2005-12 & 5.468 & 5.225 & 2.62 & 629.250 \\
\hline $2006-6$ & 5.453 & 5.344 & 1.76 & 412.148 \\
\hline 2006-12 & 5.578 & 5.473 & 1.90 & 513.713 \\
\hline $2007-6$ & 5.574 & 5.372 & 4.18 & 1124.884 \\
\hline 2007-12 & 5.671 & 5.480 & 3.71 & 1126.476 \\
\hline $2008-6$ & 5.684 & 5.419 & 4.42 & 1333.696 \\
\hline 2008-12 & 5.848 & 5.640 & 4.15 & 1421.567 \\
\hline $2009-6$ & 5.822 & 5.721 & 1.22 & 410.194 \\
\hline 2009-12 & 5.926 & 5.877 & 1.33 & 507.198 \\
\hline $2010-6$ & 5.958 & 5.858 & 1.83 & 711.103 \\
\hline 2010-12 & 6.062 & 5.969 & 1.82 & 814.117 \\
\hline $2011-6$ & 6.073 & 5.984 & 2.50 & 1112.054 \\
\hline 2011-12 & 6.215 & 6.000 & 2.81 & 1425.785 \\
\hline $2012-6$ & 6.194 & 6.137 & 2.04 & 1006.494 \\
\hline 2012-12 & 6.286 & 6.186 & 2.04 & 1112.467 \\
\hline $2013-6$ & 6.285 & 6.200 & 1.50 & 809.745 \\
\hline 2013-12 & 6.356 & 6.257 & 1.56 & 912.290 \\
\hline $2014-6$ & 6.338 & 6.229 & 1.95 & 1112.320 \\
\hline 2014-12 & 6.392 & 6.280 & 2.18 & 1312.887 \\
\hline $2015-6$ & 6.367 & 6.297 & 2.57 & 1507.945 \\
\hline 2015-12 & 6.438 & 6.318 & 3.34 & 2114.062 \\
\hline
\end{tabular}

Note: In the list of Year, year-6 represents the first half of the year and year-12 represents the second half of the year. The data comes from CSMAR database. 
which enhanced the confidence of foreign investors in the CNY, the offshore stock of CNY rose again. In 2012, with the influence of the European debt crisis and the expectation of the Federal Reserve to raise interest rates, the US dollar gradually strengthened, and China's economic growth slowed gradually, leading to a decline in the appreciation potential of CNY and even a tendency to depreciate and causing $\mathrm{CNY}$ overseas stock to appear the decline tendency.

However, with the establishment of the BRICS Development Bank in July 2014 and the establishment of the AIIB in October of the same year, China's voice in the Asian region and the world has gradually increased, increasing the confidence of foreign investors in CNY, as well as the Stock Connect between Shanghai and Hong Kong, the formal appearance of RQDII and the further expansion of RQFII stimulate the demand of foreign investors for CNY, and the stock of offshore CNY stops falling and rebounds. By November 2015, the International Monetary Fund (IMF) officially announced that CNY will be included in the SDR currency basket. The internationalization of CNY has reached a new milestone, further enhancing its international status and credibility.

\section{The Factors Influencing Model of Internationalization of CNY}

\subsection{The Influencing Factors of CNY Internationalization}

There are many factors affecting the internationalization of a country's currency. This paper holds that the level of GDP development and the balance of payments structure of a country will have an important impact on the internationalization of its currency.

Mundell (2003) believes that a currency can become a key currency is determined by the country's economic strength [13]. Eichengreen (2011) in [6], and Subramanian and Kessler (2012) in [14] believed that the huge economic scale and foreign trade flow promote the process of CNY internationalization. Thus, this paper considers the economic scale of a country is an important factor affecting the internationalization of a country's currency. Because the larger a country's economy is, the more goods and services it will account for in its currency, the greater the propensity of other people to hold its currency, and the more internationalized the currency. At the same time, the stronger a country's economy is, the more stable its currency is, the easier it is to become a reserve currency for other countries' central banks and private sector, and the more internationalized the currency is. The international status of currencies such as the dollar and the euro depends on its strong economic base.

According to the traditional theory of currency internationalization, the surplus of current account is beneficial to increase a country's external net financial assets and foreign net financial claims, thus improving the country's ability to pay abroad. Yu Daoxian and Wang Yun (2015) believe that when a country has a perennial current account surplus, it tends to think that its economy, especially its manufacturing development level, is in an advantageous position compared 
with other countries in [10]. This has a positive effect on the internationalization of a country's currency. However, if a country has a surplus of capital and financial accounts for many years, it is difficult for domestic capital to be exported to the outside world, and it is difficult for a country's currency to expand its circulation abroad, thus hindering the process of currency internationalization. Frankel (2012) in [15], hold that the current controlled CNY exchange rate, imperfect financial market and strict capital account control in China are not conducive to the internationalization of CNY.

\subsection{The Trend Analysis of Influencing Factors}

For the past 20 years, economy in China has developed rapidly. The average annual growth rate of GDP in China is as high as $8 \%$. Figure 3 shows the growth of GDP in China from 1999 to 2015. It can be seen that China's total economic volume has been increasing since 1999. In 2014, China's GDP exceeded the $\$ 10$ trillion mark for the first time and became the second largest economy in the world. From 1999 to 2005, the proportion of GDP in the world rose slowly. From 2006 to 2012, China's GDP accounted for the world total share rose rapidly, and exceeded $10 \%$ in 2011. Until 2015, China's annual GDP reached US $\$ 10.71$ trillion, accounting for $13.36 \%$ of the world's GDP, and its economic influence continued to expand.

With the continuous expansion of China's opening to the outside world, China's balance of payments presents a large surplus. As can be seen from Figure 4, between 1999 and 2014, except for the small deficit in China's capital and financial accounts in 2012, the balance of payments structure in the rest of the year remained in a state of both surplus. In 2015, The structure of China's balance of payments has changed by a large margin, as shown by the large deficit in capital and financial items, which far exceeds the margin of surplus in the current account, that is, the total balance of payments of China shows a deficit in that year. The large deficit in capital and financial accounts indicates that a large amount of domestic capital flows overseas, reflecting the strengthening of the internationalization of CNY.

Figure 5 shows the percentage of the balance of current account and capital and finance account to the current year's GDP. It can be seen that the surplus of China's current account in 2004-2007 has been enlarged by a large margin, which shows that the level of our manufacturing industry has been greatly improved, and China's export of products and services has been stimulated. Although, after the global financial crisis broke out in 2008, the world economy grew slowly, which affected China's export growth, but in 2011-2015, China's current account surplus as a proportion of GDP can still be maintained at the level of about $2 \%$. However, the balance of capital and financial items in China is almost surplus before 2015, which represents the insufficient export of capital and is not conducive to the process of CNY internationalization. It is worth noting that China's capital and financial account has a large deficit in 2015, indicating that a large amount of domestic capital invested abroad in that year, 


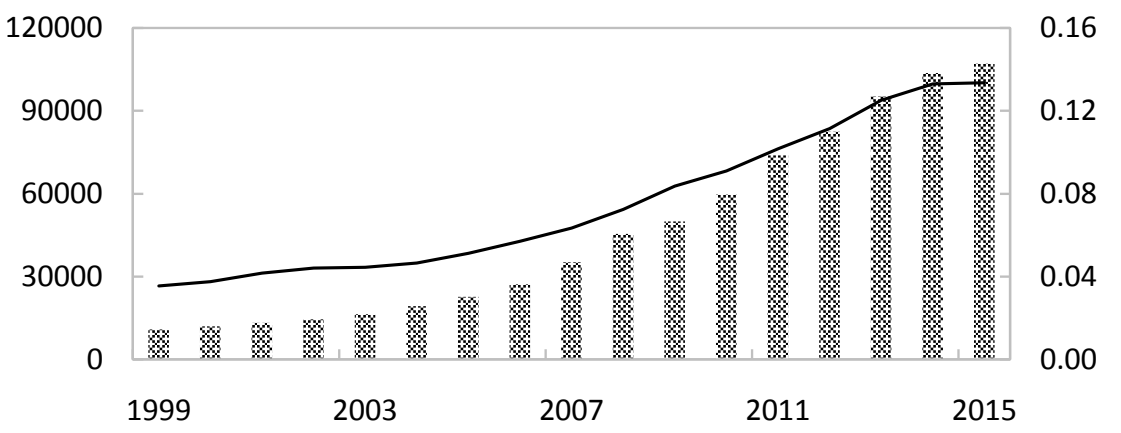

$\$$ Chinese GDP(Trillion) — The percentage of Chinese GDP in the world

Figure 3. GDP growth in China in $1999-2015^{3}$.

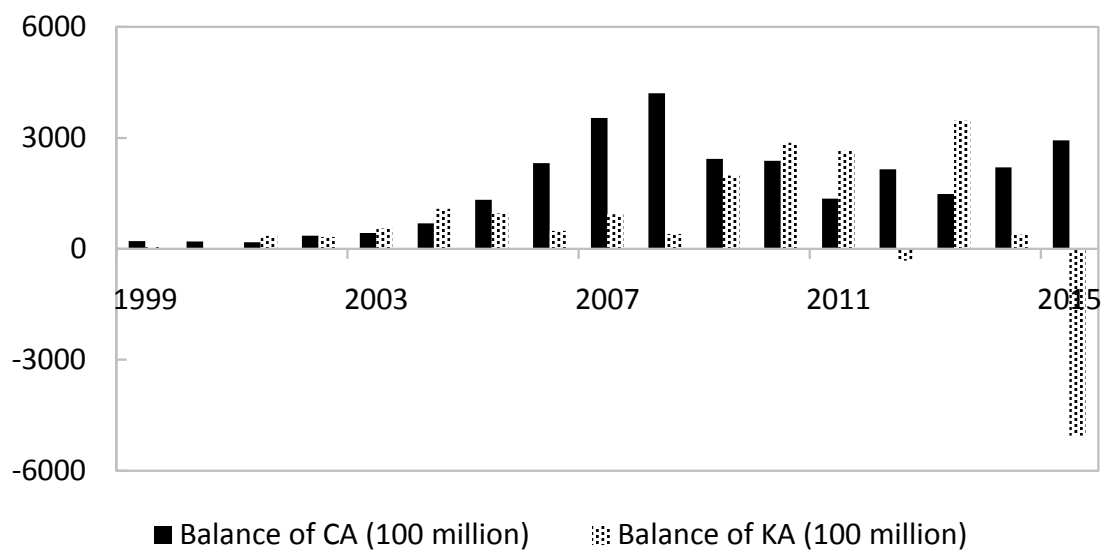

Figure 4. China's balance of payments in 1999-2015.

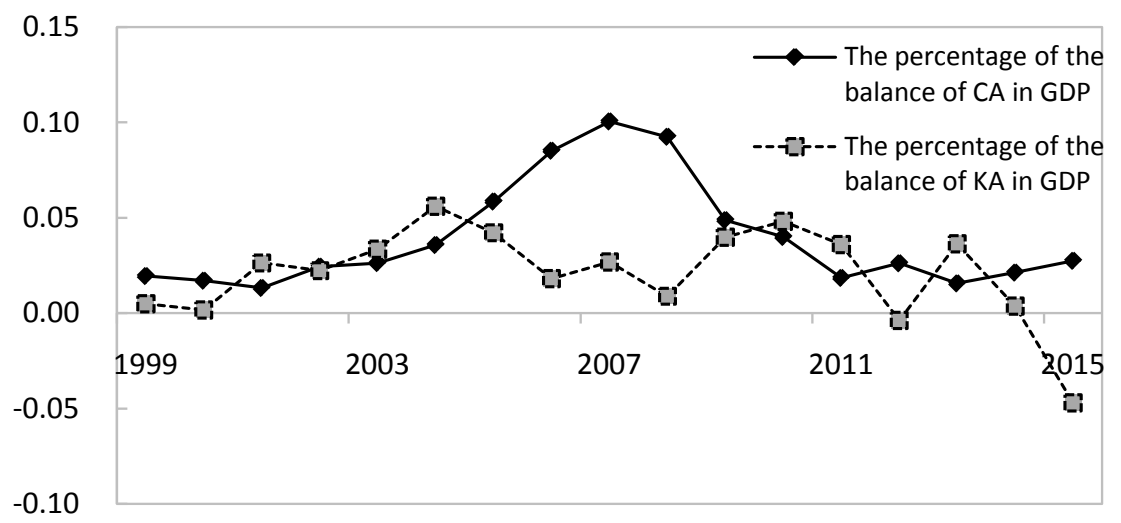

Figure 5. China's CA, KA balance as a proportion of GDP in 1999-2015 .

which is conducive to strengthening the international status of CNY, thus promoting its internationalization.

\subsection{The Influencing Factors Model of CNY Internationalization}

In this paper, we use the estimation of offshore CNY stock scale $\mathrm{m}$ as the crite-

${ }^{3}$ The data comes from CSMAR database.

${ }^{4} \mathrm{~A}$ negative number in the balance of KA in 2015 means a deficit in that year.

${ }^{5} \mathrm{~A}$ positive percentage represents a surplus for that year and a negative one for a deficit. 
rion to measure the degree of CNY internationalization and select the time series cointegration analysis method to analyze the development level of China's GDP and the influence of the balance of payments structure on the process of CNY internationalization. The time span of the sample data is 1999-2015. The explanatory variables are as follows: $A_{t}$, the percentage of Chinese GDP in the world GDP as a measure of its economic scale, and the data source is the World Bank database and the CSMAR database; $B_{t}$, the percentage of the current account balance in China's GDP in the current year, and the data source is the database of China Foreign Exchange Administration (CFEA); The percentage of China's capital and financial account balance in its GDP is $C_{t}$ and the data source is also CFEA. The model is as follows:

$$
\ln m_{t}=\beta_{0}+\beta_{1} \cdot A_{t}+\beta_{2} \cdot B_{t}+\beta_{3} \cdot C_{t}+\varepsilon_{t}
$$

Considering the non-stationary character of time series economic data, it is necessary to test the unit root of each variable before cointegration analysis. The specific test results are shown in Table 5.

Table 5 shows that the original series of all variables in model (3) can not refuse the original assumption that the unit root exists at a significant level of $5 \%$, that is, the original series is non-stationary. However, after the second order difference treatment, all variables can reject the original assumption that there is no unit root at the significant level of $1 \%$, that is, there is no unit root, and the series are stable, so the variables in the model are all second-order monolithic series. The base of cointegration analysis is satisfied.

Table 5. ADF test of variables in the influencing factors model of CNY internationalization.

\begin{tabular}{cccc}
\hline Variables & Method $(\mathrm{C}, \mathrm{T}, \mathrm{n})$ & ADF-Value & $P$-Value \\
\hline $\ln m_{t}$ & $(\mathrm{C}, \mathrm{T}, 0)$ & -3.481 & 0.076 \\
$A_{t}$ & $(\mathrm{C}, \mathrm{T}, 0)$ & -1.794 & 0.659 \\
$B_{t}$ & $(\mathrm{C}, 0,0)$ & -2.932 & 0.067 \\
$C_{t}$ & $(0,0,0)$ & -1.359 & 0.155 \\
$D\left(\ln m_{t}\right)$ & $(0,0,1)$ & -5.065 & 0.000 \\
$D\left(A_{t}\right)$ & $(0,0,1)$ & -0.878 & 0.319 \\
$D\left(B_{t}\right)$ & $(0,0,1)$ & -2.438 & 0.019 \\
$D\left(C_{t}\right)$ & $(0,0,1)$ & -3.917 & 0.001 \\
$D\left(\ln m_{t}, 2\right)$ & $(0,0,2)$ & -8.919 & 0.000 \\
$D\left(A_{t}, 2\right)$ & $(0,0,2)$ & -2.959 & 0.006 \\
$D\left(B_{t}, 2\right)$ & $(0,0,2)$ & -5.234 & 0.000 \\
$D\left(C_{t}, 2\right)$ & $(0,0,2)$ & -4.612 & 0.000 \\
\hline
\end{tabular}

Note: $D$ is the difference operator, $\mathrm{C}$ represents the test equation with intercept term, $\mathrm{T}$ represents the test equation with time trend term, and $\mathrm{n}$ represents the delay order of the variable. The data comes from World Bank database, CSMAR database and the database of China Foreign Exchange Administration respectively. 
According to the results of Table 5, this paper uses the E-G cointegration test to investigate whether there is cointegration relationship among the variables in the model (3). Firstly, the ordinary least square regression is used and the result is shown in Table 6.

Then, we test the residual error series $e_{2}$, and the result is shown in Table 7. According to Table 7, it can be found that the residual series $e_{2}$ of the regression model rejects the original assumption of the existence of unit root at the level of $1 \%$ significance, that is, the residual sequence $e_{2}$ does not have the unit root, and it is a stationary series. This indicates that there is a long-term cointegration relationship between the explanatory variables and the explained variables in the influencing factors model of $\mathrm{CNY}$ internationalization.

According to the regression results of model (3), we can see that the every $1 \%$ expansion of proportion of China's GDP in the world GDP will theoretically increase the natural logarithmic of CNY offshore stock by 0.2822 , and the absolute value of the coefficient of this variable is the largest, which is proved that the economic scale has the greatest influence on the internationalization process of CNY. The regression results fully show that the economic scale of a country is an important factor affecting the internationalization of its currency. The US dollar can become the international currency really benefits from its huge economic volume. The larger a country's economy is, the greater its voice in the world will be, and its currency will be more easily accepted by the world's people and naturally become the worldwide currency. In addition, for every $1 \%$ expansion of the surplus balance of the current account to GDP, the natural logarithmic of the offshore stock of CNY will expand by 0.1866 , indicating that the surplus in the current account contributes to the process of internationalization of CNY. This is consistent with the traditional theory of currency internationalization mentioned above, that is, the surplus in the current account is conducive to financing its capital and financial account, realizing the increase of a country's net external financial claims and assets, and promoting the export of a country's currency to the outside world to drive the internationalization of their currencies. However,

Table 6. The estimated results of Influencing Factors Model of CNY Internationalization.

\begin{tabular}{cccccc}
\hline Variable & Intercept & $A$ & $B$ & $C$ & $R^{2}$ \\
\hline Coef. & 4.791 & 28.219 & 18.659 & -7.769 & \\
Std.err & 0.548 & 5.048 & 5.890 & 7.084 & 0.743 \\
$P$-value & 0.000 & 0.000 & 0.007 & 0.291 &
\end{tabular}

Note: The data sources are the World Bank database, CSMAR database and the database of CFEA.

Table 7. The unit root check of residual error series $e_{2}$.

\begin{tabular}{cccc}
\hline Variables & Method $(\mathrm{C}, \mathrm{T}, \mathrm{n})$ & ADF-Value & $P$-Value \\
\hline$e_{2}$ & $(0,0,0)$ & -5.163 & 0.000 \\
\hline
\end{tabular}

Note: $\mathrm{C}$ represents the test equation with intercept term, $\mathrm{T}$ represents the test equation with time trend term, and $\mathrm{n}$ represents the delay order of the variable. 
the regression coefficient of the balance of capital and financial account is not significant in the model, so this paper can not explain the relationship between capital and financial account balance and CNY internationalization empirically. With the capital account opening gradually in China, it is believed that the relationship between the two can be obtained in the future research.

\section{Conclusions}

In this paper, based on the monetary demand function proposed by Friedman (1956) in [11], we use the semi-annual data from 1990-1998 to estimate the domestic demand function model of CNY with long-term stability. According to the principle of indirect calculation, the stock of offshore CNY from 1999 to 2015 is calculated as the standard to measure the internationalization of CNY. According to the results, we find that the scale of CNY stock abroad is fluctuating and rising, indicating that the degree of CNY internationalization is increasing year by year.

Then, this paper makes an empirical study on the dynamic relationship among the scale of China's economy, the structure of international payments and the stock of CNY abroad by using cointegration analysis. We find that there is a long-term cointegration relationship between offshore CNY stock and China's economic scale and current account balance. In the long run, the larger the scale of our economy, the greater the positive effect on the offshore stock of $\mathrm{CNY}$, which promotes the process of CNY internationalization. The larger the balance of current account is, the more it can promote the increase of offshore stock of CNY. The expansion of the capital and financial account surplus will lead to a decline in the offshore stock of the CNY, which inhibits the internationalization of CNY. However, the regression coefficient is not significant. The main reason probably is that the capital and financial account in China currently are artificially controlled by the government, and capital is still not in the state of free flow inside and outside China.

\section{Conflicts of Interest}

The author declares no conflicts of interest regarding the publication of this paper.

\section{References}

[1] Chinn, M. and Frankel, J. (2005) Will the Euro Eventually Surpass the Dollar as Leading International Reserve Currency? NBER Working Paper No. 11510.

[2] Li, D.K. and Liu, L.L. (2008) Two-Track System to Promote CNY Internationalization. China Finance, No. 10, 43.

[3] Jiang, B.K. and Zhang, Q.L. (2005) Monetary Internationalization: a Review of Studies on Conditions and Effects. New Finance, No. 8, 33-35.

[4] Zhang, G.P. (2011) A Simple Method to Measure the Degree of Monetary Internationalization and the Promotion of CNY Internationalization Level. Financial Review, 3, 40-48, 124. 
[5] Zhang, Y.M. ()2013 Research on the Measure and Countermeasure of CNY Internationalization Based on Matlab Principal Component Analysis. Shanghai Finance, No. 2, 11-17.

[6] Eichengreen, B. (2011) The Renminbi as an International Currency. Journal of Policy Modeling, 33, 723-730. https://doi.org/10.1016/j.jpolmod.2011.07.004

[7] Wei, H., Dai, J.P. and Jin, X.T. (2010) Measure of Currency Internationalization, Determinants and Countermeasures of CNY Internationalization. Guizhou Social Sciences, No. 9, 95-100.

[8] Kannan, P. (2009) On the Welfare benefits of an international currency. European Economic Review, 53, 588-606. https://doi.org/10.1016/j.euroecorev.2008.10.003

[9] Liu, Y.J. (2012) Econometric Analysis on the Evolution of International Reserve Currency on the Feasibility of CNY Internationalization. International Financial Research, No. 4, 71-78.

[10] Yu, D.X. and Wang, Y. (2015) Stock of CNY, Balance of Payments and Internationalization of CNY. Economic Theory and Economic Management, No. 4, 31-36.

[11] Friedman, M. (1956) The Quantity Theory of Money-A Restatement. University of Chicago Press, Chicago, 129-138.

[12] Hawkins, J.R. and Leung, C. (1997) The Demand for Hong Kong Dollar. Quarterly Bulletin, No. 5, 2-13.

[13] Mundell, R.A. (2003) The International Financial System and Outlook for Asian Currency Collaboration. The Journal of Finance, 58, 3-7.

[14] Subramanian, A. and Kessler, M. (2012) The Renminbi Bloc is Here: Asia Down, Rest of the World to Go? Peterson Institute for International Economics, Working Paper, WP 12-19.

[15] Frankel, J. (2012) Internationalization of the CNY and Historical Precedents. Journal of Economic Integration, No. 27, 329-365. 